INTERNATIONAL JOURNAL OF ADVANCED ENGINEERING

AND BUSINESS SCIENCES (IJAEBS)

Journal homepage: International Journal of Advanced Engineering and Business Sciences (ekb.eg)

\title{
Parallel Distribution Compensation PID Based on Takagi-Sugeno Fuzzy Model Applied On DC Motor
}

\section{A. Abdel Ghanya*, Mohamed. A. Shamseldin ${ }^{b}$, Abdel Azim Mohamed ${ }^{c}$}

${ }^{a}$ Department of Electrical Engineering, Faculty of Engineering October 6 University, email: $\underline{\text { mghany1988@ hotmail.com }}$

${ }^{\mathrm{b}}$ Future University in Egypt, Faculty of Engineering, email: Mohamed.abelbbar@fue.edu.eg

${ }^{\mathrm{d}}$ Department of Electrical Engineering, Faculty of Engineering October 6 University, email: am.salem90@yahoo.com

*Corresponding author: Email address: mghany1988@hotmail.com

Received: 07-April-2021

Accepted: 19-April-2021

Published: 20-April-2021

\section{ABSTRACT}

Most of the industrial controllers in use today utilize PID controllers. In this paper, a new Parallel Distribution Compensator PID'S controller at several operating points, under parameters variations and external disturbances for the DC motor drive system. The parameters of PID's controllers were obtained at each operating point based on harmony search optimization. An effective cost function was used to perform the offline optimization. Three optimal PID's controllers were attained for each operating point individually. The fuzzy Takagi-Sugeno (TS) can be defined as the suitable PID controller for the corresponding operating point. The simulation results provided that Parallel Distribution Takagi-Sugeno PID's controller can be updated the suitable PID controller at several operating points so, it has good dynamic response with different types of disturbances (sudden load, variable load, and speed tracking) compared to the fixed optimal PID controller. Also, it can switch the better PID controller at a suitable time.

Keywords: Takagi-Sugeno, Fuzzy, Parallel Distribution, Power System Control, PID 
M. A. Abdel Ghany et al., IJAEBS (2021), (2), (1), (36-58) 


\section{INTRODUCTION}

Because of their high reliabilities, flexibilities and low costs, DC motors are widely used in industrial applications, robot manipulators and home appliances where speed and position control of motor are required. PID controllers are commonly used for motor control applications because of their simple structures and intuitionally comprehensible control algorithms. Controller parameters are generally tuned using hand-tuning or Ziegler-Nichols frequency response method. Both of these methods have successful results but long time and effort are required to obtain a satisfactory system response. Two main problems encountered in motor control are the timevarying nature of motor parameters under operating conditions and existence of noise in system loop.

Analysis and control of complex, nonlinear and/or time-varying systems is a challenging task using conventional methods because of uncertainties. Fuzzy set theory (Zadeh , 1965) which led to a new control method called Fuzzy Control[1] which is able to cope with system uncertainties. DC motor control is generally realized by adjusting the terminal voltage applied to the armature but other methods such as adjusting the field resistance, inserting a resistor in series with the armature circuit are also available.

Ziegler-Nichols [2] frequency response method is usually used to adjust the parameters of the PID controllers. However,

It is needed to get the system into the oscillation mode to realize the tuning procedure. The proposed approach uses both fuzzy controllers and response optimization method to obtain the approximate values of the controller parameters. Then the parameters may be slightly varied to obtain the user-defined performance of the real-time control system. Then the parameters may be slightly varied to obtain the user-defined performance of the real-time control system. Thus, it's an actual problem to design adaptive PID controllers without getting the system into the oscillation mode. Here the mathematical model of a dc motor is used to obtain a transfer function between shaft position and applied armature voltage. This model is then built in MATLAB Simulink. Then design and tuning of proportional-integral-derivative (PID) controllers are reviewed in Simulink with the proposed design procedure. 


\section{DC Motor Model}

In armature control of separately excited DC motors, the voltage applied to the armature of the motor is adjusted without changing the voltage applied to the field. Figure 1 shows a separately excited DC motor equivalent model.

$$
\begin{gathered}
v_{a}(\mathrm{t})=\mathrm{R}_{\mathrm{a}} \mathrm{i}_{\mathrm{a}}(\mathrm{t})+\mathrm{L}_{\mathrm{a}} \frac{\mathrm{di}_{\mathrm{a}}(\mathrm{t})}{\mathrm{dt}}+\mathrm{e}_{\mathrm{b}} \\
\mathrm{e}_{\mathrm{b}}=K_{f} i_{f} \omega(\mathrm{t}) \\
\mathrm{T}(\mathrm{t})=K_{v} i_{f} i_{a}(\mathrm{t})=D_{m} \omega(\mathrm{t})+J_{m} \frac{\mathrm{d} \omega(\mathrm{t})}{\mathrm{dt}}+T_{l} \\
\mathrm{~T}(\mathrm{t})=K_{t} i_{a}(\mathrm{t})
\end{gathered}
$$

From these equations, the transfer function is derived as follows:

$$
\begin{gathered}
v_{a}(\mathrm{t})-\mathrm{e}_{\mathrm{b}}=\mathrm{R}_{\mathrm{a}} \mathrm{i}_{\mathrm{a}}(\mathrm{t})+\mathrm{L}_{\mathrm{a}} \frac{\mathrm{di}_{\mathrm{a}}(\mathrm{t})}{\mathrm{dt}} \\
V_{a}(\mathrm{~s})-K_{t} \omega(\mathrm{s})=\left(\mathrm{R}_{\mathrm{a}}+\mathrm{L}_{\mathrm{a}} \mathrm{S}\right) \mathrm{I}_{\mathrm{a}}(\mathrm{s}) \\
K_{t} i_{a}(\mathrm{t})-T_{l}=D_{m} \omega(\mathrm{t})+J_{m} \frac{\mathrm{d} \omega(\mathrm{t})}{\mathrm{dt}} \\
K_{t} I_{a}(\mathrm{~s})-T_{l}=\left(D_{m}+J_{m} \mathrm{~S}\right) \omega(\mathrm{s}) \\
\frac{\mathrm{I}_{\mathrm{a}}(\mathrm{s})}{V_{a}(\mathrm{~s})-\mathrm{e}_{\mathrm{b}}}=\frac{1}{\left(\mathrm{R}_{\mathrm{a}}+\mathrm{L}_{\mathrm{a}} \mathrm{S}\right)} \\
\frac{\omega(\mathrm{s})}{K_{t} I_{a}(\mathrm{~s})-T_{l}}=\frac{1}{\left(D_{m}+J_{m} \mathrm{~S}\right)}
\end{gathered}
$$

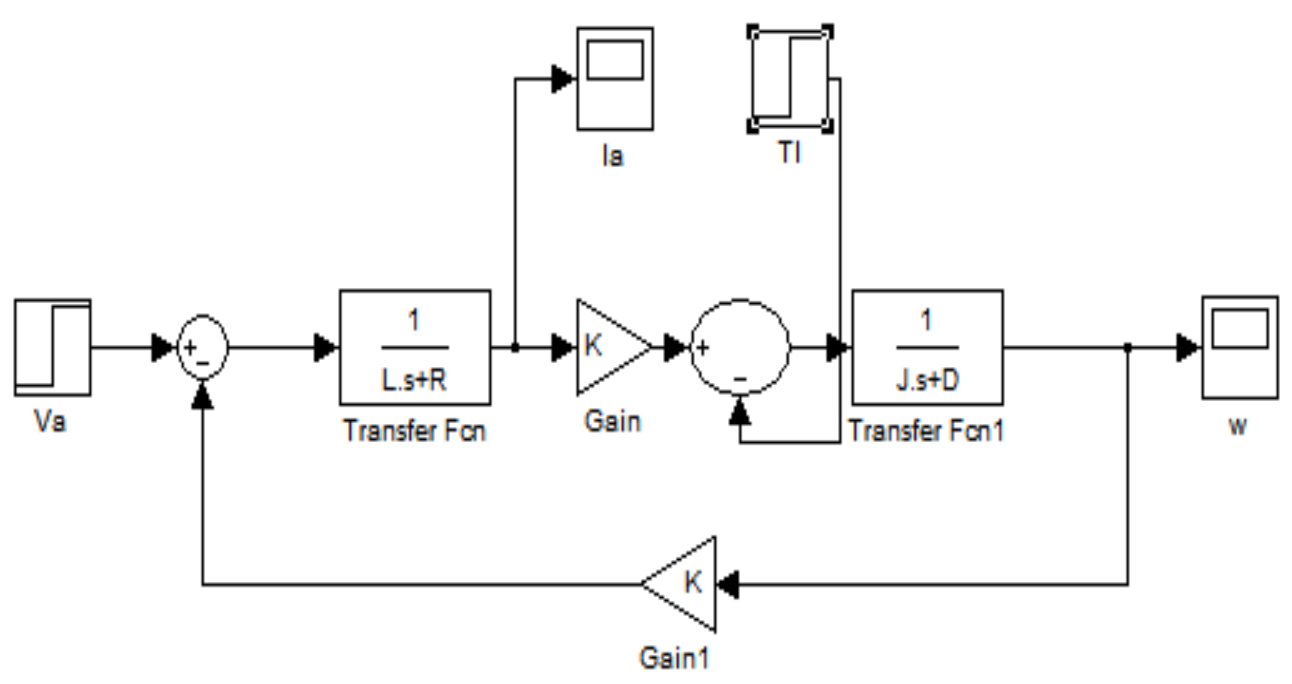

Fig. 1. DC motor Simulink block diagram. 
Or from substituting the developed mechanical torque into the electrical equation:

$$
\begin{gathered}
I_{a}(\mathrm{~s})=\left[\left(D_{m}+J_{m} \mathrm{~S}\right) \omega(\mathrm{s})+T_{l}\right] / K_{t} \\
V_{a}(\mathrm{~s})=\left[\left(\mathrm{R}_{\mathrm{a}}+\mathrm{L}_{\mathrm{a}} \mathrm{S}\right)\left[\left(D_{m}+J_{m} \mathrm{~S}\right) \omega(\mathrm{s})+T_{l}\right] / K_{t}\right]+K_{t} \omega(\mathrm{s}) \\
V_{a}(\mathrm{~s})=\left[\left(\mathrm{R}_{\mathrm{a}}+\mathrm{L}_{\mathrm{a}} \mathrm{S}\right)\left[\left(D_{m}+J_{m} \mathrm{~S}\right) \omega(\mathrm{s})\right] / K_{t}\right]+K_{t} \omega(\mathrm{s}) \\
\frac{\omega(\mathrm{s})}{V_{a}(\mathrm{~s})}=\frac{K_{t}}{\mathrm{~L}_{\mathrm{a}} J_{m} S^{2}+\left(\mathrm{R}_{\mathrm{a}} J_{m}+\mathrm{L}_{\mathrm{a}} D_{m}\right) S+\mathrm{R}_{\mathrm{a}} D_{m}+K_{t}{ }^{2}}
\end{gathered}
$$

Where:

$\mathrm{L}_{\mathrm{a}}=0.1214 \mathrm{H}$

$\mathrm{R}_{\mathrm{a}}=11.4 \Omega$

$J_{m}=0.02215 \mathrm{Kg} \cdot \mathrm{m}^{2}$

$D_{m}=0.002953 \mathrm{~N}-\mathrm{m} \mathrm{s} / \mathrm{rad}$

$K_{t}=1.28 \mathrm{~N}-\mathrm{m}-A(\mathrm{~V}-\mathrm{s}-\mathrm{rad})$

To get the damping ratio and the natural frequency:

$$
\begin{gathered}
\mathrm{L}_{\mathrm{a}} J_{m} S^{2}+\left(\mathrm{R}_{\mathrm{a}} J_{m}+\mathrm{L}_{\mathrm{a}} D_{m}\right) S+\mathrm{R}_{\mathrm{a}} D_{m}+K_{t}{ }^{2} \\
S^{2}+\left(\frac{\mathrm{R}_{\mathrm{a}}}{L_{m}}+\frac{D_{m}}{\mathrm{~J}_{\mathrm{m}}}\right) S+\frac{\mathrm{R}_{\mathrm{a}} D_{m}+K_{t}{ }^{2}}{\mathrm{~L}_{\mathrm{a}} J_{m}} \\
S^{2}+2 \zeta \omega_{\mathrm{n}} S+\omega_{\mathrm{n}}{ }^{2} \\
\omega_{n}{ }^{2}=621.8 \\
\omega_{n}=24.9 \approx 25 \mathrm{~Hz} \\
2 \zeta \omega_{\mathrm{n}}=94.04 \\
\zeta=1.88
\end{gathered}
$$

\section{THE PROPOSED CONTROLLER}

This section illustrates the design steps of proposed The Parallel Distributed Compensation PID'S to improve the performance the frequency $(\Delta \mathrm{f})$ and the controllers outputs of Egyptian load frequency control system.

\subsection{The Parallel Distributed Compensation -PID 'S}

The Parallel Distributed Compensation (PDC) offers a procedure to design a fuzzy controller from a given T-S fuzzy model [25]. To realize the PDC, a controlled object (nonlinear system) is 
first represented by a T-S fuzzy model [26]. In the PDC design, each control rule is designed from the corresponding rule of a T-S fuzzy model [27]. The constructing following fuzzy controller via the PDC is given by [28]:

\section{Control Rule $i$ :}

If $Z_{I}(t)$ is $M_{i I} \ldots$ and $Z_{P}(t)$ is $M_{i P}$ then $u(t)=u^{(i)}=k_{p}{ }^{(i)} . e+{k_{i}}^{(i)} \cdot \int e d t+k_{d}{ }^{(i)} . \Delta e$

Where

$$
i=1,2, \ldots r
$$

For building the model using a TS fuzzy model, the ranges of each parameter (pn1, pn2, pn3) according to the table (2) divides to named membership functions, as shown in Figure 2. The membership functions are assumed to be overlapped triangular shapes that have their middle vertexes positioned at the given crisp values and in a manner that assures that at any other crisp value is covered by exactly 2 membership functions.

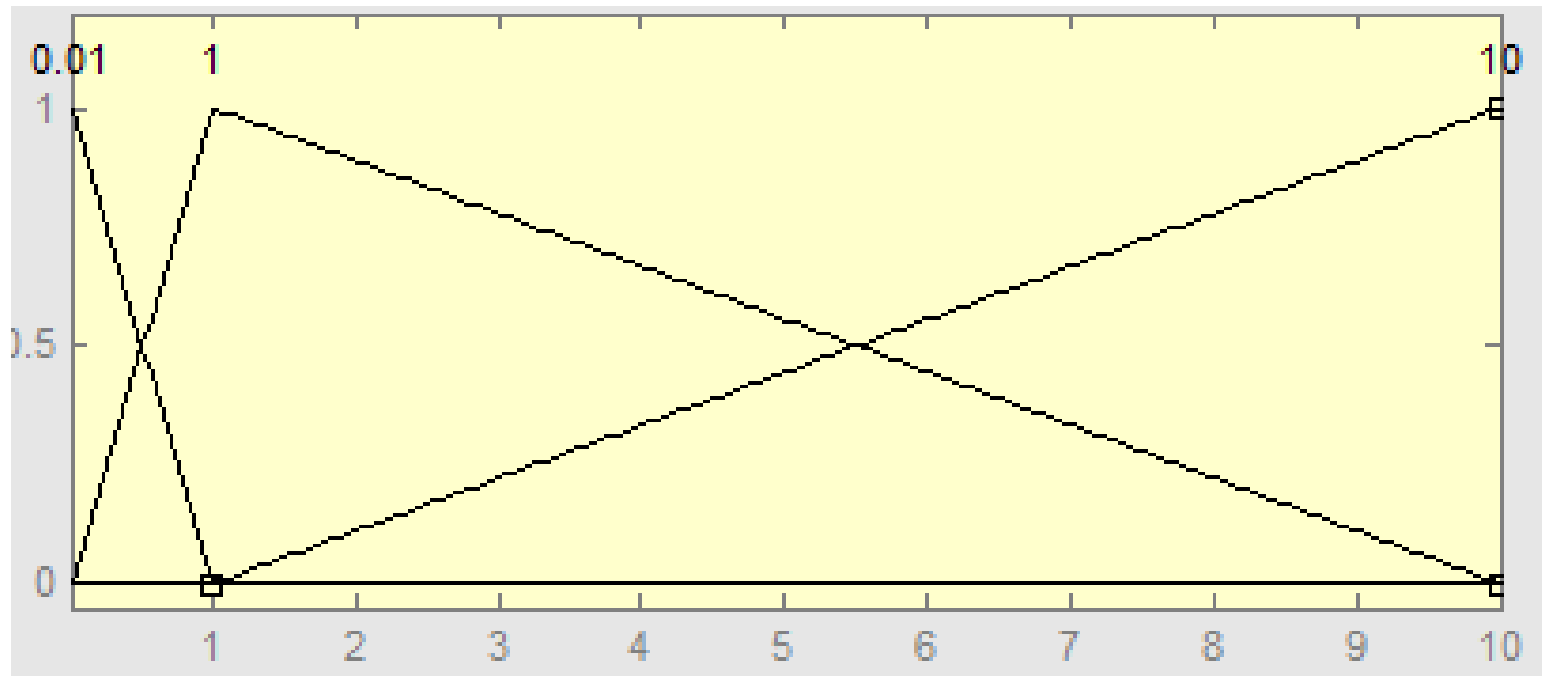

Fig. 2. Membership functions for J

\subsection{The Steps of controller design:}

1- Calculate the weight for each rule as follows:

The weight of $i_{\text {th }}$ rule is $w_{i}=\min \left(m f_{1}\left(p_{n 1}\right), m f_{2}\left(p_{n 2}\right), m f_{3}\left(p_{n 3}\right)\right)$ 
The ith weight is achieved by using triangle functions and a min block as seen in Figure 6 product block can also used instead of $\mathrm{min}$ ):

2- Calculate the output of the controller as demonstrated in Figure 7 by implementing the following equation:

$$
u=\frac{\sum_{i=1}^{r}\left(u^{(i)} \cdot W_{i}\right)}{\sum_{i=1}^{r} W_{i}}
$$

Let's take for example, Rule 1:

IF pn1 is about 0.2529 (the value of pn1 that corresponds to rule 1) AND pn2 is about 0.6107 (the value of pn2 that corresponds to rule 1) AND pn3 is about 0.1364 (the value of pn3 that corresponds to rule 1) then

$$
u=u^{(1)}=1.8912 e+0.088697 \int e d t+0.9733 . \Delta e
$$

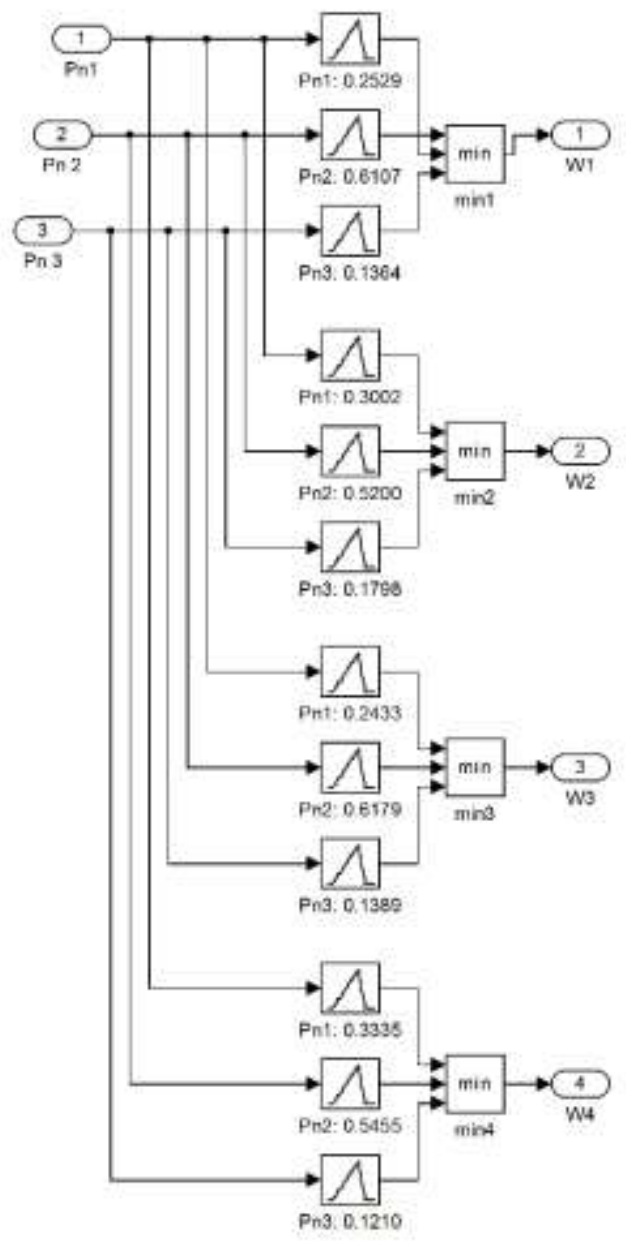


Fig. 3. Calculating the weight of one fuzzy rule

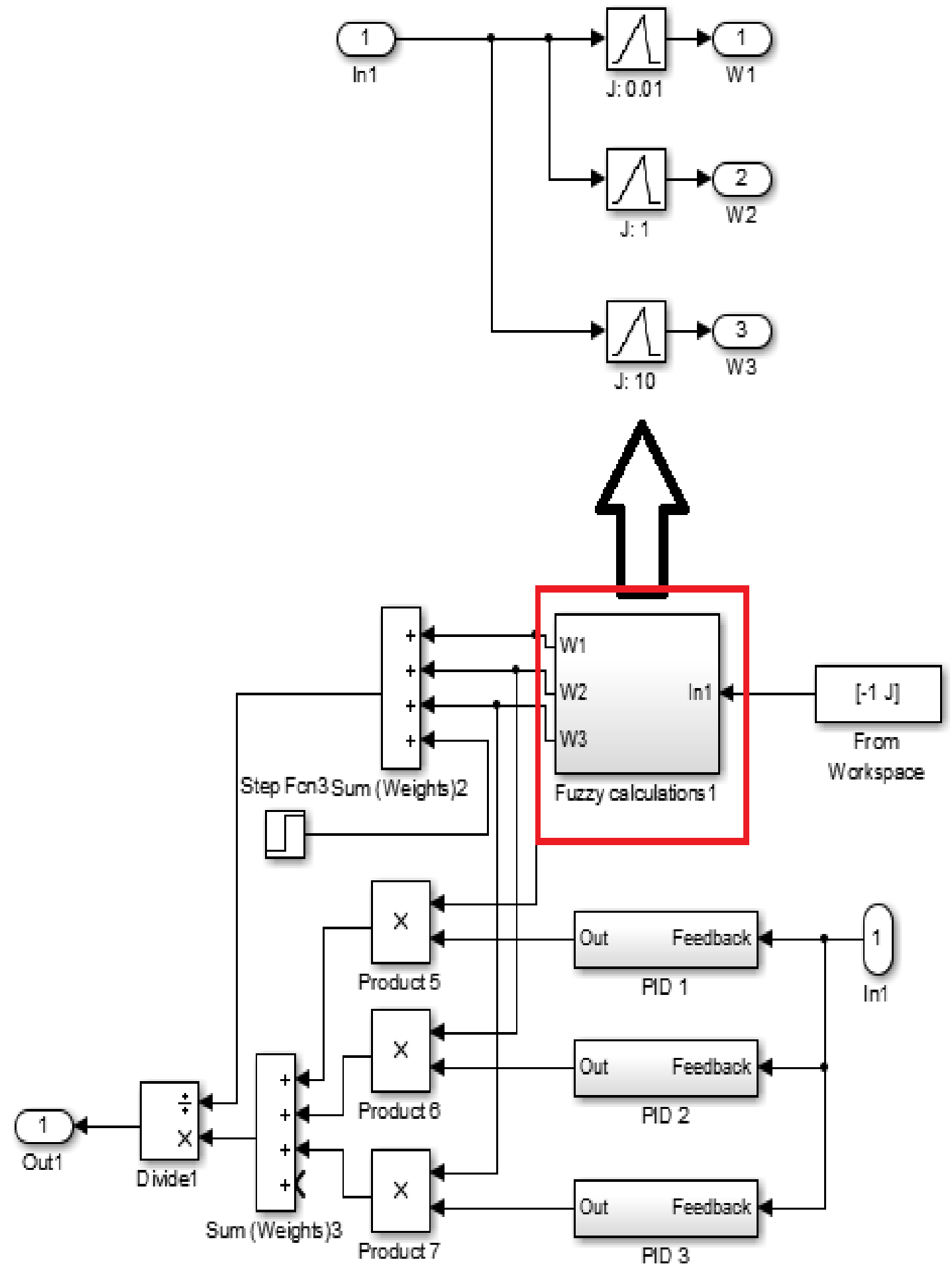

Fig. 4. The block diagram of the PDC PID controller

M. A. Abdel Ghany et al., IJAEBS (2021), (2), (1), (36-58) 


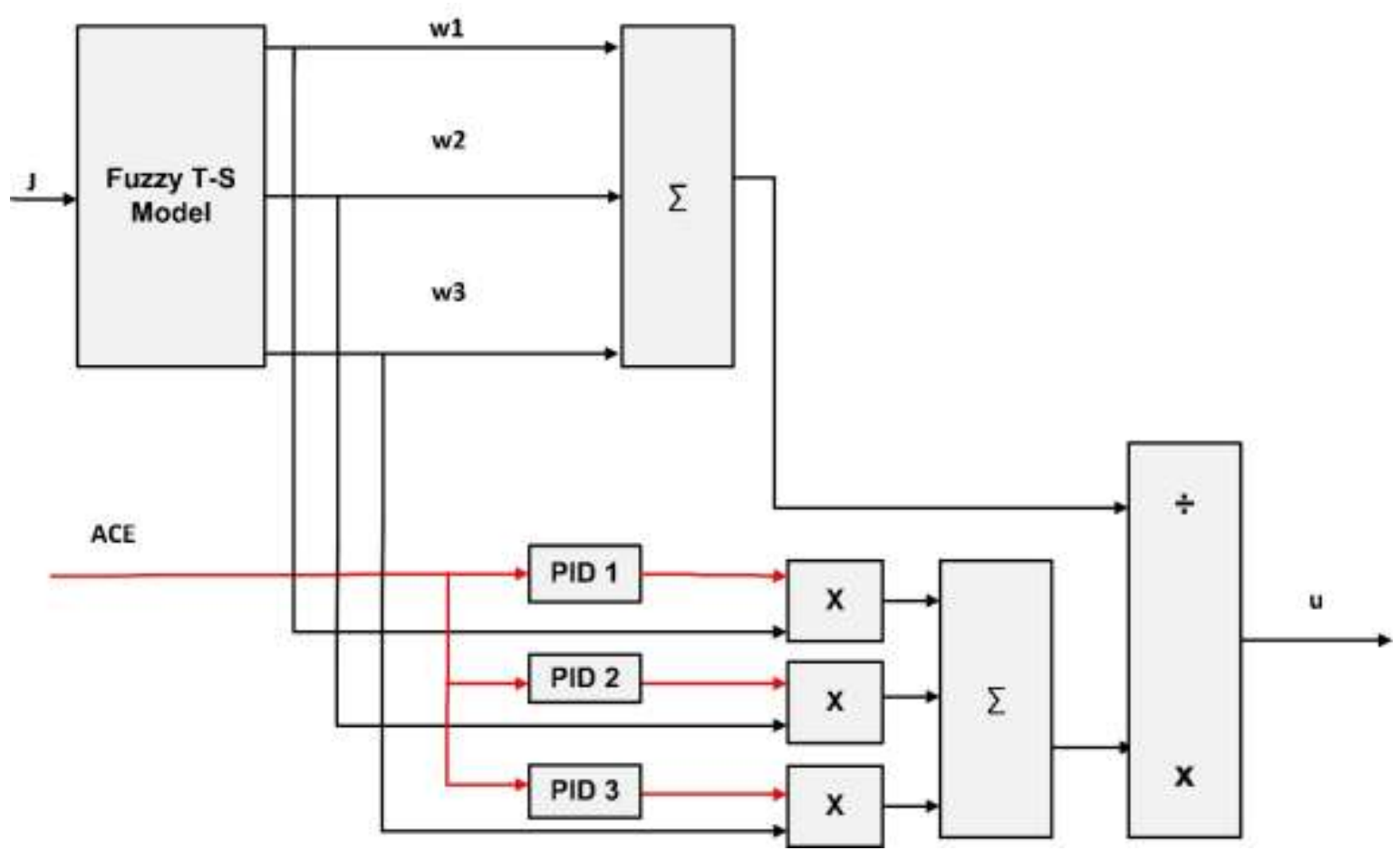

Fig. 5. Best Choice of Operating Points Using TS Fuzzy Model

\subsection{Harmony Search Optimization Technique}

The challenge point in the PID and FOPID controllers are selecting the appropriate parameters for a certain controlled plant. There are several methods to find the parameters of FOPID controller for example, try and error and Ziegler-Nichols method but, most of these techniques are rough roads. In this paper, the harmony search optimization technique will be used to obtain the optimal values of FOPID controller parameters according to the objective function as shown in Eq (3) [22].

$$
f=\frac{1}{\left(1-e^{-\beta}\right)\left(M_{p}+e_{s s}\right)+e^{-\beta}\left(t_{s}-t_{r}\right)}
$$

Where $e_{s s}$ is the steady state error, $M_{p}$ is the overshoot of system response, $t_{s}$ is the settling time and $t_{r}$ is the rise time. Also, this objective function is able to compromise the designer requirements using the weighting parameter value $(\beta)$. The parameter is set larger than 0.7 to reduce over shoot and steady state error. 
If this parameter is adjusting smaller than 0.7 the rise time and settling time will be reduced. Harmony search (HS) was suggested by Zong Woo Geem in 2001 [31]. It is well known that HS is a phenomenon-mimicking algorithm inspired by the improvisation process of musicians [32]. The initial population of Harmony Memory (HM) is chosen randomly. HM consists of Harmony Memory Solution (HMS) vectors.

Table 1 shows the obtained parameters of TSMFOPID controller based on harmony search optimization technique.

Table 1: TSMFOPID parameters.

\begin{tabular}{clllll}
\hline $\begin{array}{c}\text { TSMFOPID } \\
\text { parameters }\end{array}$ & Kp & Kd & vd & ki & vi \\
\hline $\begin{array}{c}\text { Parameters } \\
\text { values }\end{array}$ & 9.5603 & 5.3506 & 0.23714 & 2.5926 & 0.922 \\
\hline
\end{tabular}

Both of conventional toolbox of FOPID and the Takaji-Sugeno (TS) modified FOPID (TSMFOPID) have the same response through the simulation results at different operating conditions. In addition, it is provided in [21].

$$
H M=\left[\begin{array}{ccccc}
K_{p(1,1)} & K_{i(1,2)} & K_{d(1,3)} & v d_{(1,4)} & v i_{(1,5)} \\
K_{p(2,1)} & K_{i(22)} & K_{d(2,3)} & v d_{(2,4)} & v i_{(2,5)} \\
\cdot & \cdot & \cdot & \cdot & \cdot \\
\cdot & \cdot & \cdot & \cdot & \cdot \\
\cdot & \cdot & \cdot & \cdot & \cdot \\
K_{p(H M S, 1)} & K_{i(H M S, 2)} & K_{d(H M S, 3)} & v d_{(H M S, 4)} & v i_{(H M S, 5)}
\end{array}\right]
$$

\subsection{The Simulation Results}

The simulation results are obtained using MATLAB Toolbox. Different types of disturbances are implemented to DC motor model to show the effectiveness of the proposed controllers. Many cases under disturbances with different operating points, parameter variation and parameter uncertainty are performed.

Fig. 6 shows that the performance of DC motor at normal parameters using HS-PID-1 and PDC-PID-1 controllers. The results of both controllers are identical with no overshoot. Also, the proposed controllers have the ability to track the reference speed in less time at sudden load of 
$30 \%$ of full load and $\mathrm{j} 1=0.1$ at instant 10 seconds from simulation time. Also, Fig. 7 illustrates the corresponding controller output at speed regulation and sudden load test.

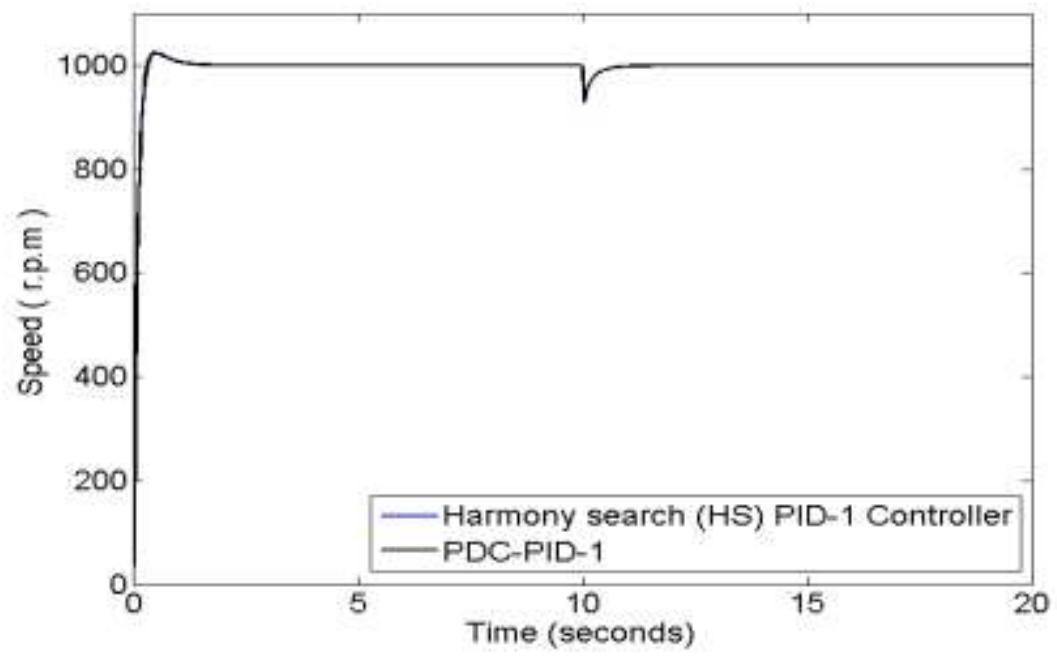

Fig. 6. The DC motor speed response at PDC-PID-1.

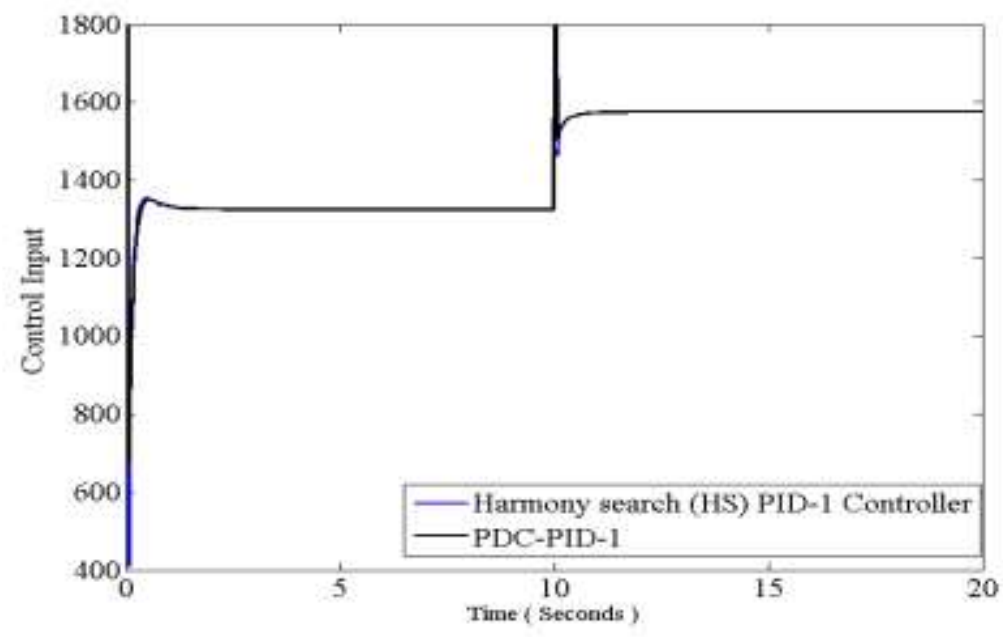

Fig. 7. The control input response at PDC-PID-1.

Fig. 8 shows that the response of DC motor at different parameters $(\mathrm{J}=0.5$.) using HS-PID-1 and PDC-PID-2 controllers. The PDC-PID-1 results is fast and with acceptable overshoot. Also, the PDC-PID-1 is sensitivity to sudden disturbance in inertia and has the ability to accommodate the disturbance in less at instant 10 seconds from simulation time. Also, Fig. 9 demonstrates the corresponding controller output at speed regulation and sudden change in inertia test. 


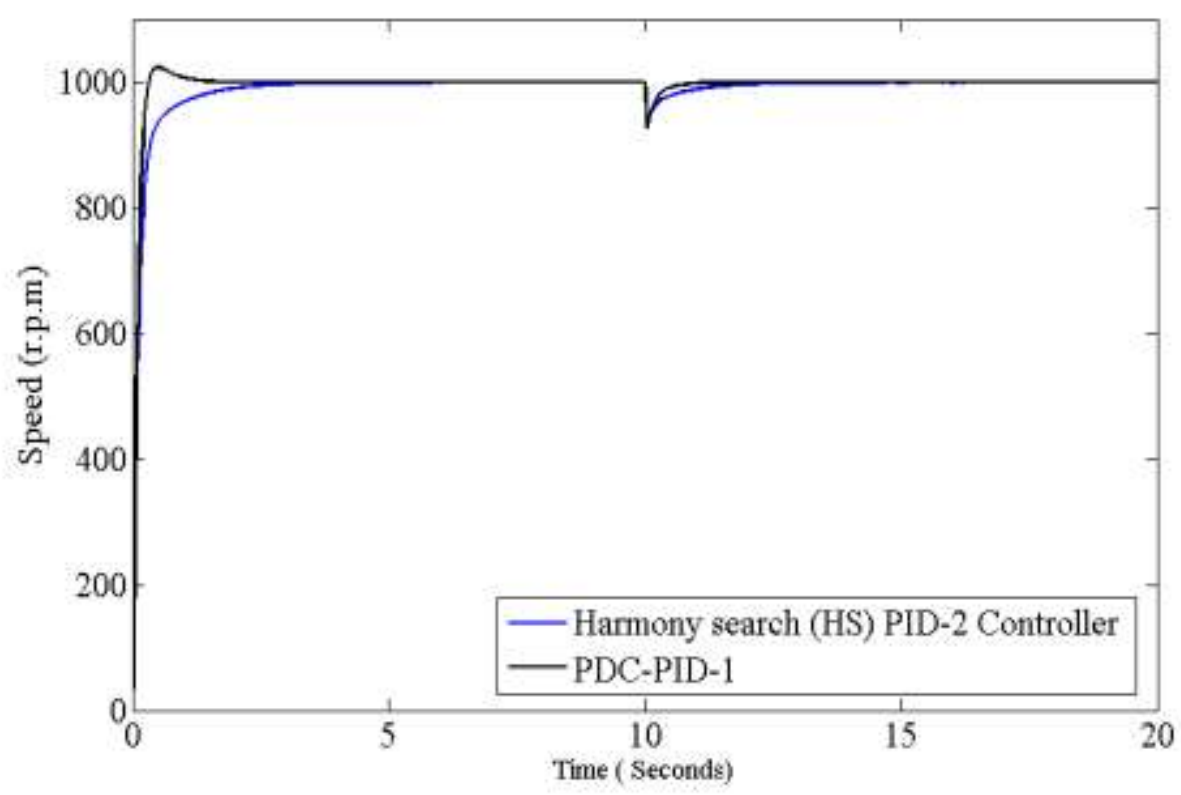

Fig. 8. The DC motor speed response at PDC-PID-1 and PID-2.

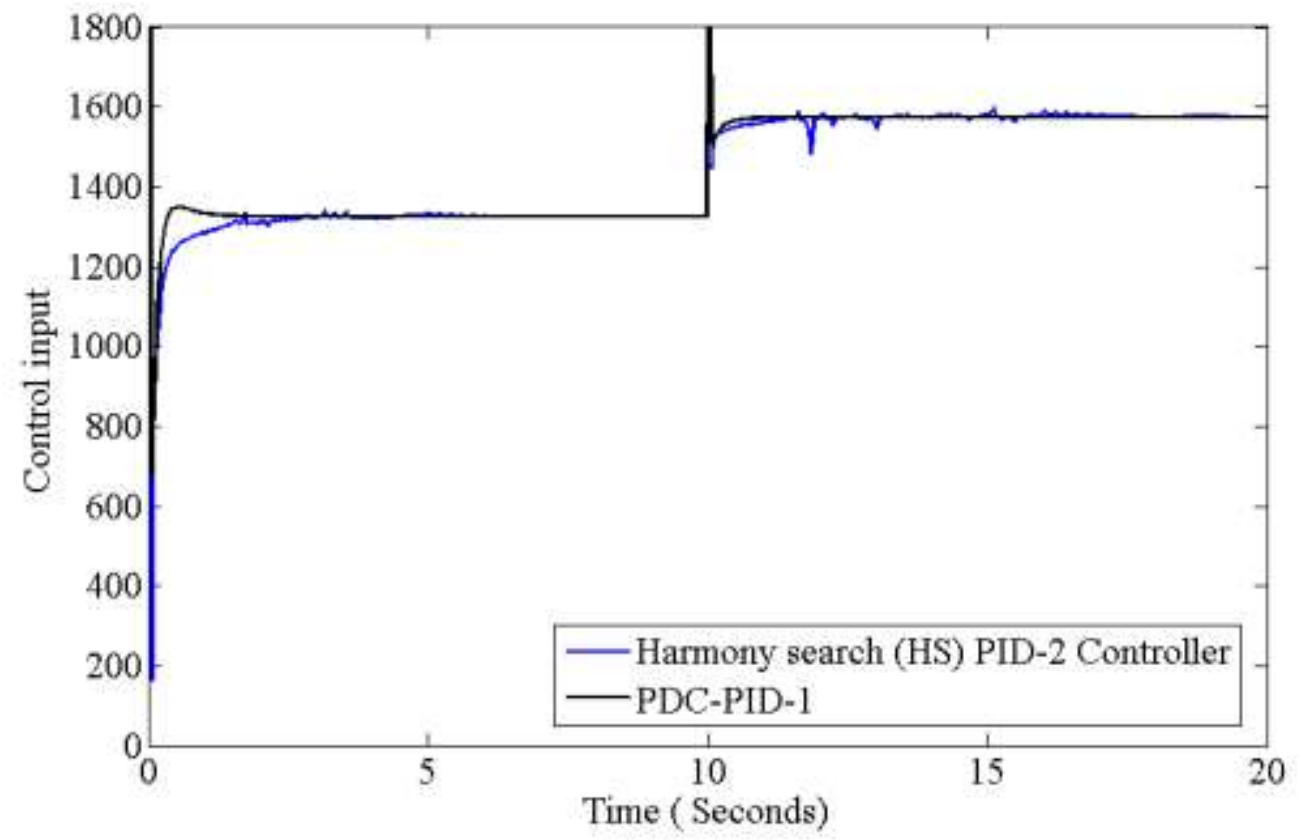

Fig. 9. The control input response at PDC-PID-1 and PID-2. 
Fig. 10 appearances that the performance of DC motor at normal parameters using HS-PID-2 and PDC-PID-3 controllers. The response of PDC-PID-3 controller is faster than the HS-PID-2. Also, the PDC-PID-3 has the ability to track the reference speed in less time at sudden change in inertia $(j=1)$ at instant 10 seconds from simulation time. Also, Fig. 11 displays the corresponding controller output at speed regulation and parameters variations test. It can be noted that the high value of controllers output at starting the simulation test.

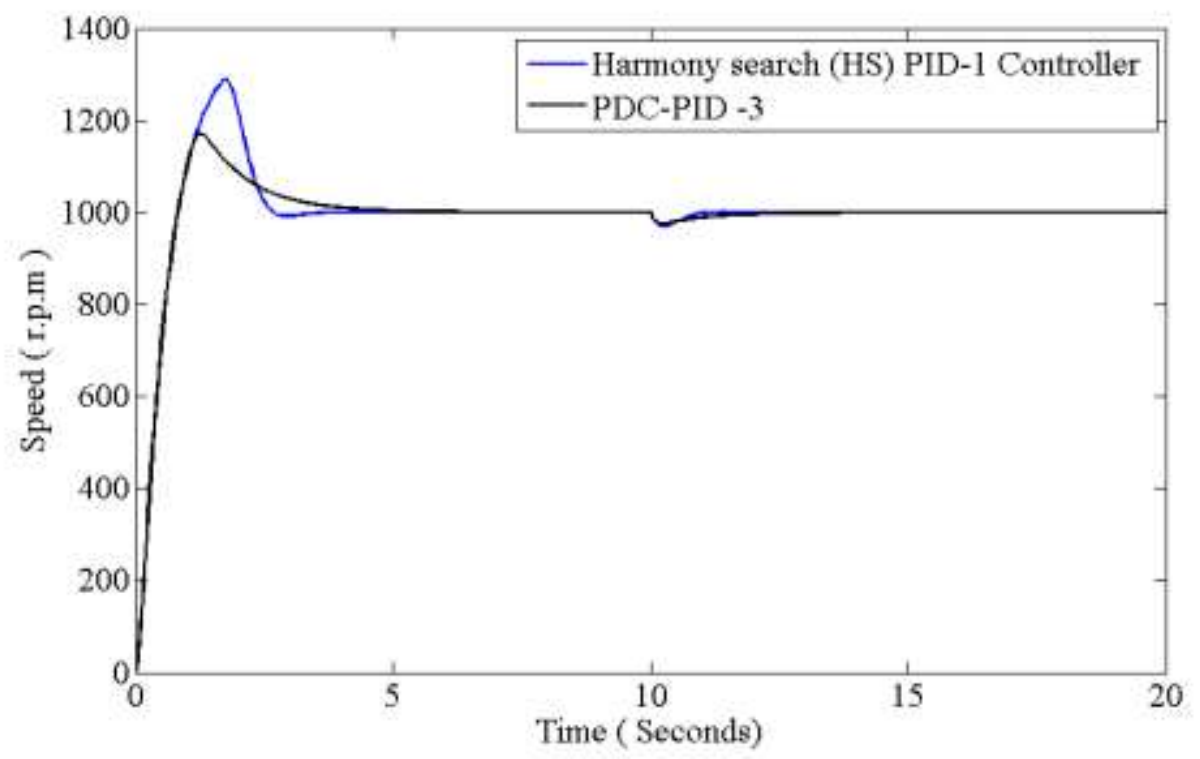

Fig. 10. The DC motor speed response at PDC-PID-3 and PID-1.

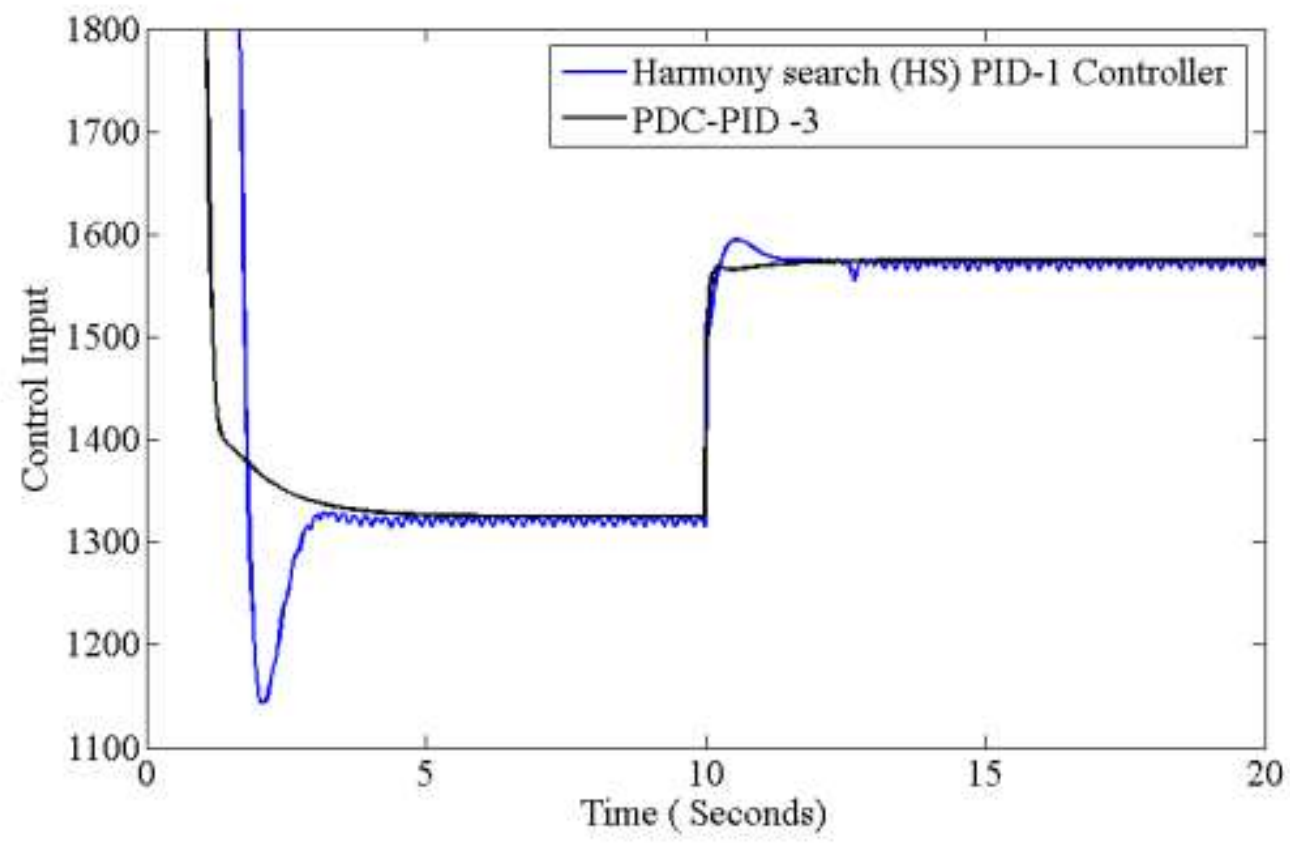

Fig. 11. The control input response at PDC-PID-3 and PID-1. 
Fig. 12 shows that the performance of DC motor at normal parameters using HS-PID-3 and PDC-PID-3 controllers. The results of both controllers are identical with no overshoot. Also, the proposed controllers have the ability to track the reference speed in less time at sudden load of $70 \%$ of full load at instant 10 seconds from simulation time. Also, Fig. 13 illustrates the corresponding controller output at speed regulation and sudden load test.

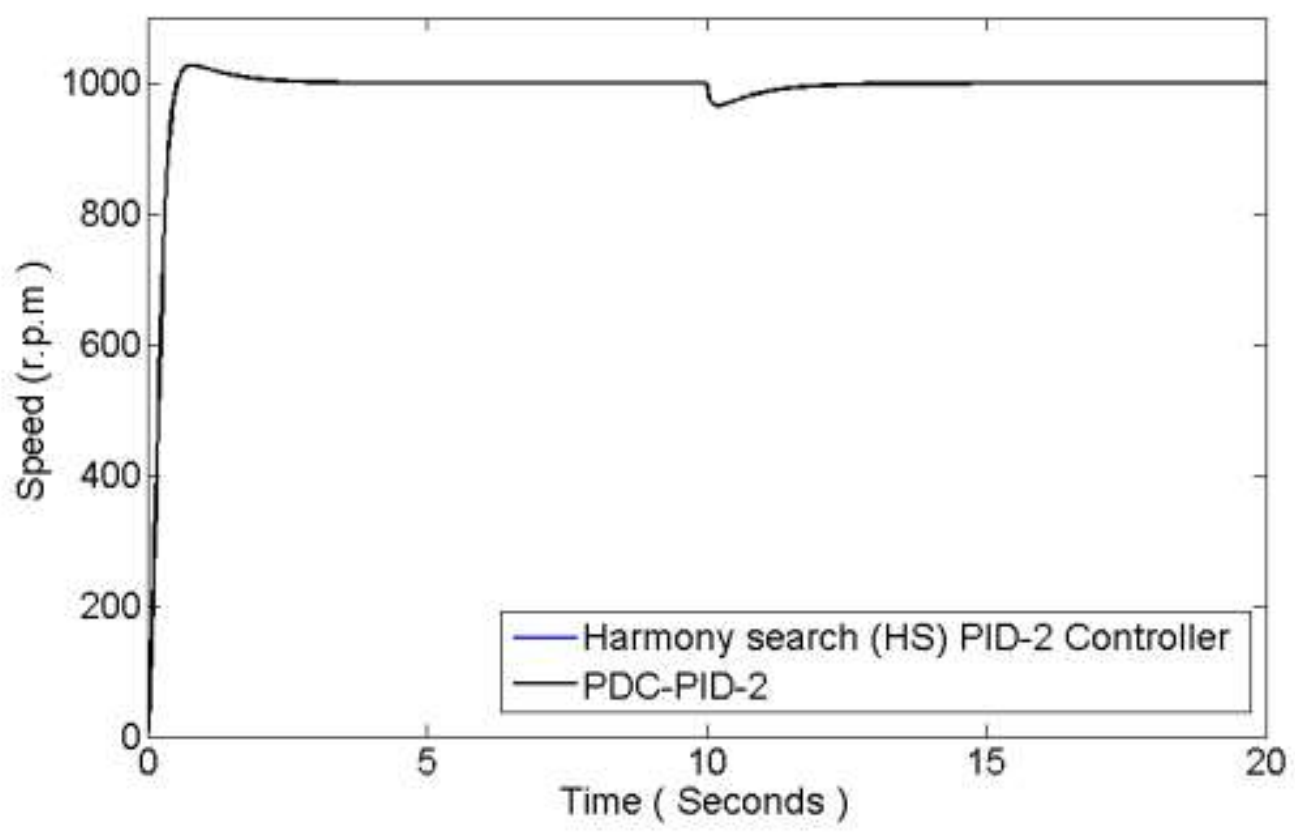

Fig. 12. The DC motor speed response at PDC-PID-2 and PID-2. 


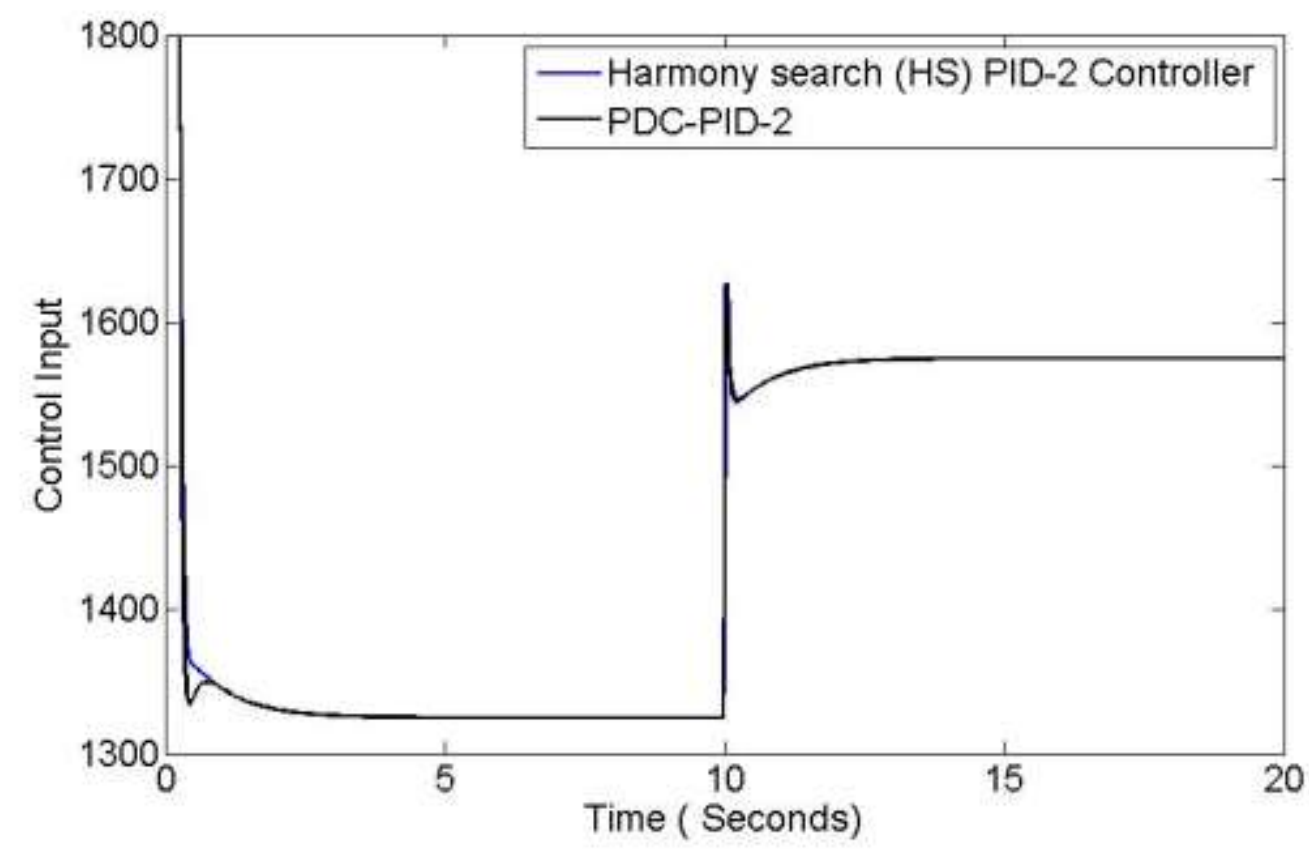

Fig. 13. The control input response at PDC-PID-2 and PID-2.

Fig. 14 demonstrates that the response of DC motor at normal parameters using HS-PID-1 and PDC-PID-1 controllers. The results of both controllers are identical with no overshoot. Also, the proposed controllers have the ability to follow the speed command rapidly at sudden load of $70 \%$ of full load at instant 10 seconds from simulation time. Also, Fig. 15 illustrates the corresponding controller output at speed regulation and sudden load test. 


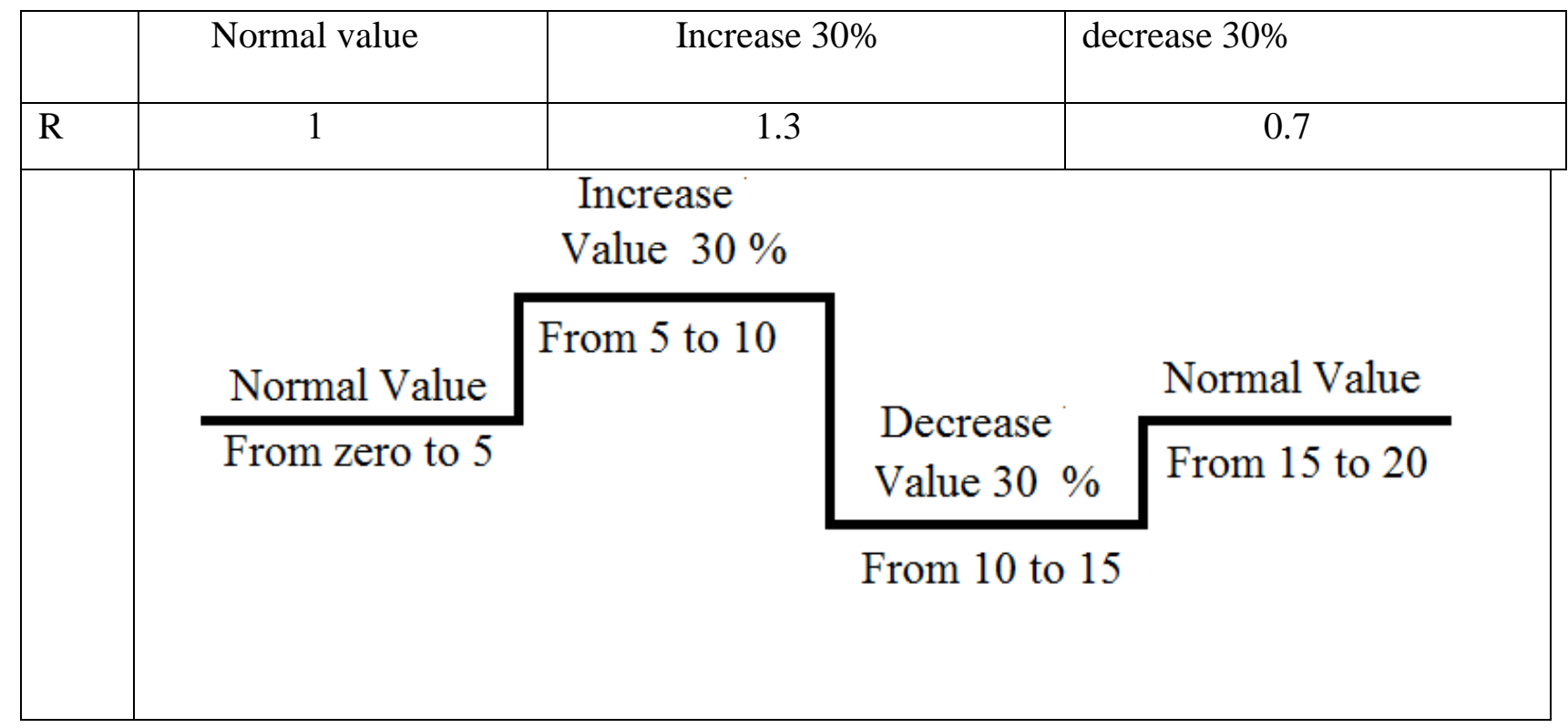

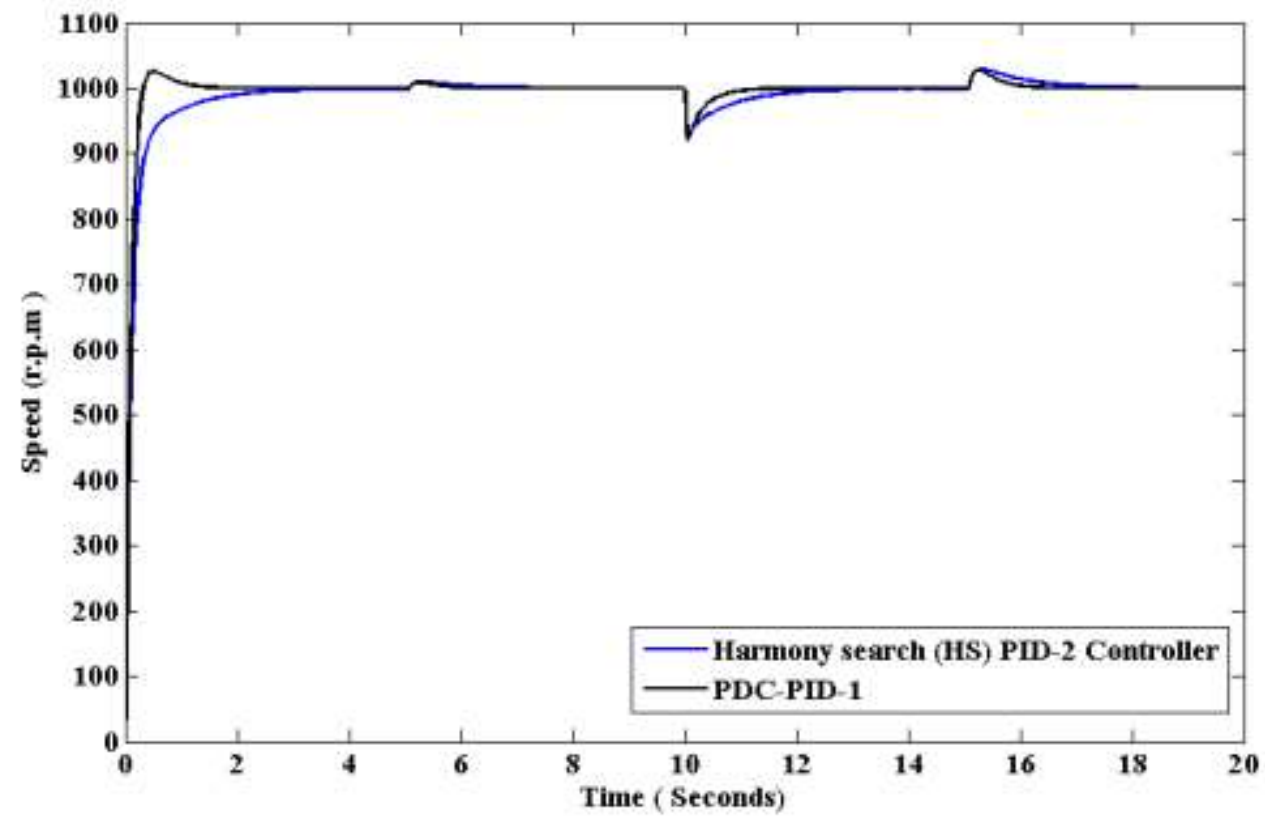

Fig. 14. The DC motor speed response at PDC-PID-1 and PID-2. 


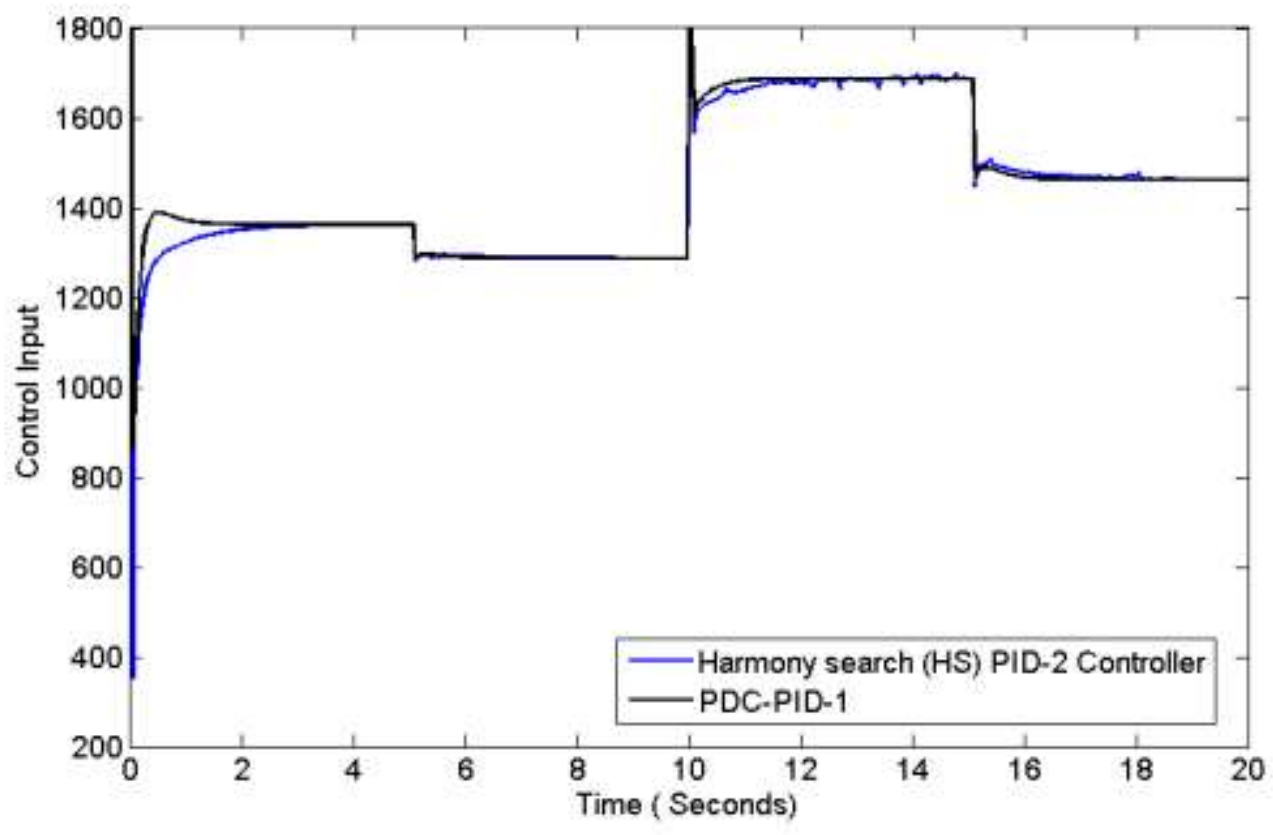

Fig. 15. The control input response at PDC-PID-1 and PID-2.

Fig. 16 displays that the response of DC motor at different operating points as in table 3 using HS-PID-2 and PDC-PID-1 controllers. The results of PDC-PID-1 controller has the fastest response (less rise time and settling time). Also, the proposed controller has the ability to follow the reference speed rapidly under parameters variations. Also, Fig. 17 shows the corresponding controller output at speed regulation and parameters variations.

\begin{tabular}{|c|c|c|c|c|c|}
\hline & Normal value & \multicolumn{2}{|c|}{ Increase $30 \%$} & & rease $30 \%$ \\
\hline \multirow[t]{4}{*}{$\mathrm{R}$} & 1 & \multicolumn{2}{|l|}{1.3} & & 0.7 \\
\hline & $\begin{array}{l}\text { Increase } \\
\text { Value } 30 \%\end{array}$ & \multicolumn{4}{|c|}{$\begin{array}{l}\text { Increase } \\
\text { Value } 30 \%\end{array}$} \\
\hline & From zero to 5 & $\begin{array}{l}\text { Decrease } \\
\text { Value } 30 \%\end{array}$ & \multicolumn{2}{|c|}{ From 10 to 15} & $\begin{array}{l}\text { Decrease } \\
\text { Value } 30 \%\end{array}$ \\
\hline & & From 5 to 10 & & & From 15 to 20 \\
\hline
\end{tabular}

M. A. Abdel Ghany et al., IJAEBS (2021), (2), (1), (36-58) 


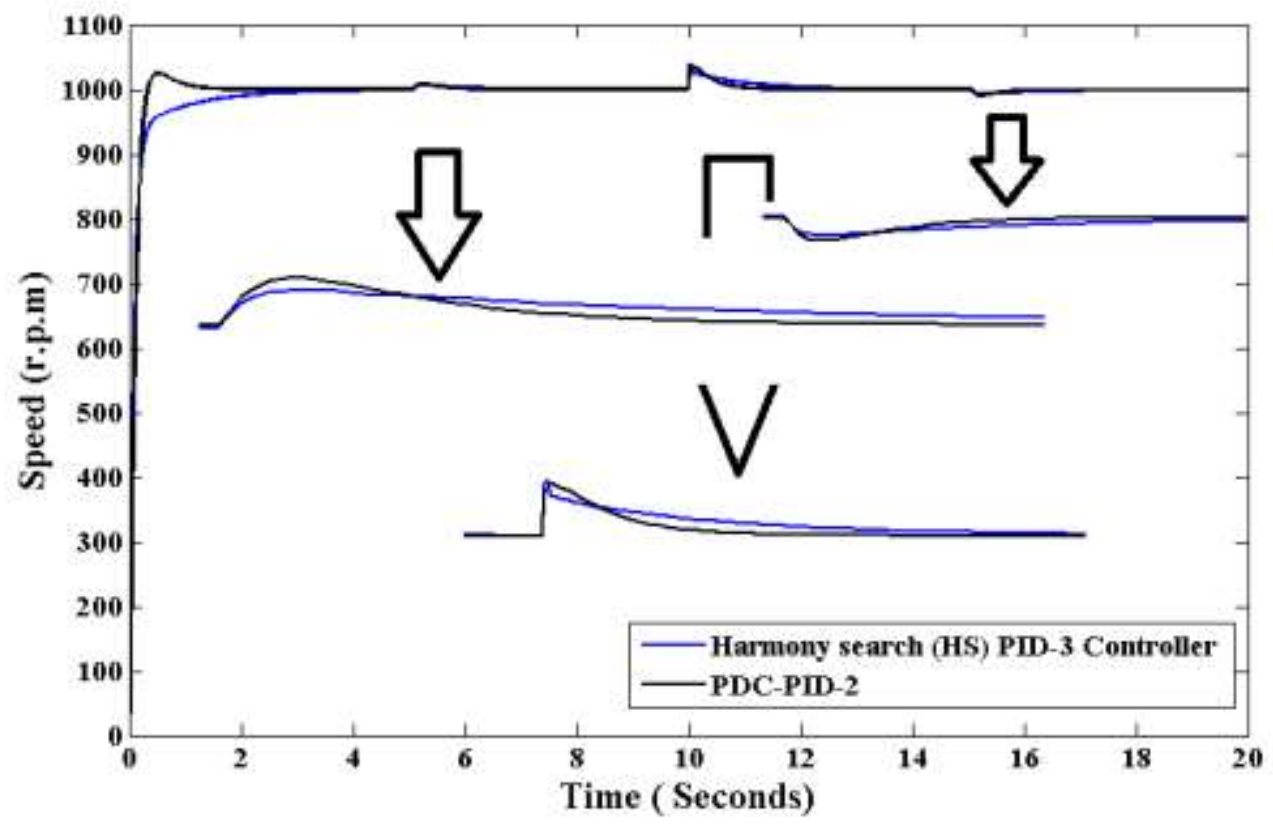

Fig. 16. The DC motor speed response at PDC-PID-2 and PID-3. 


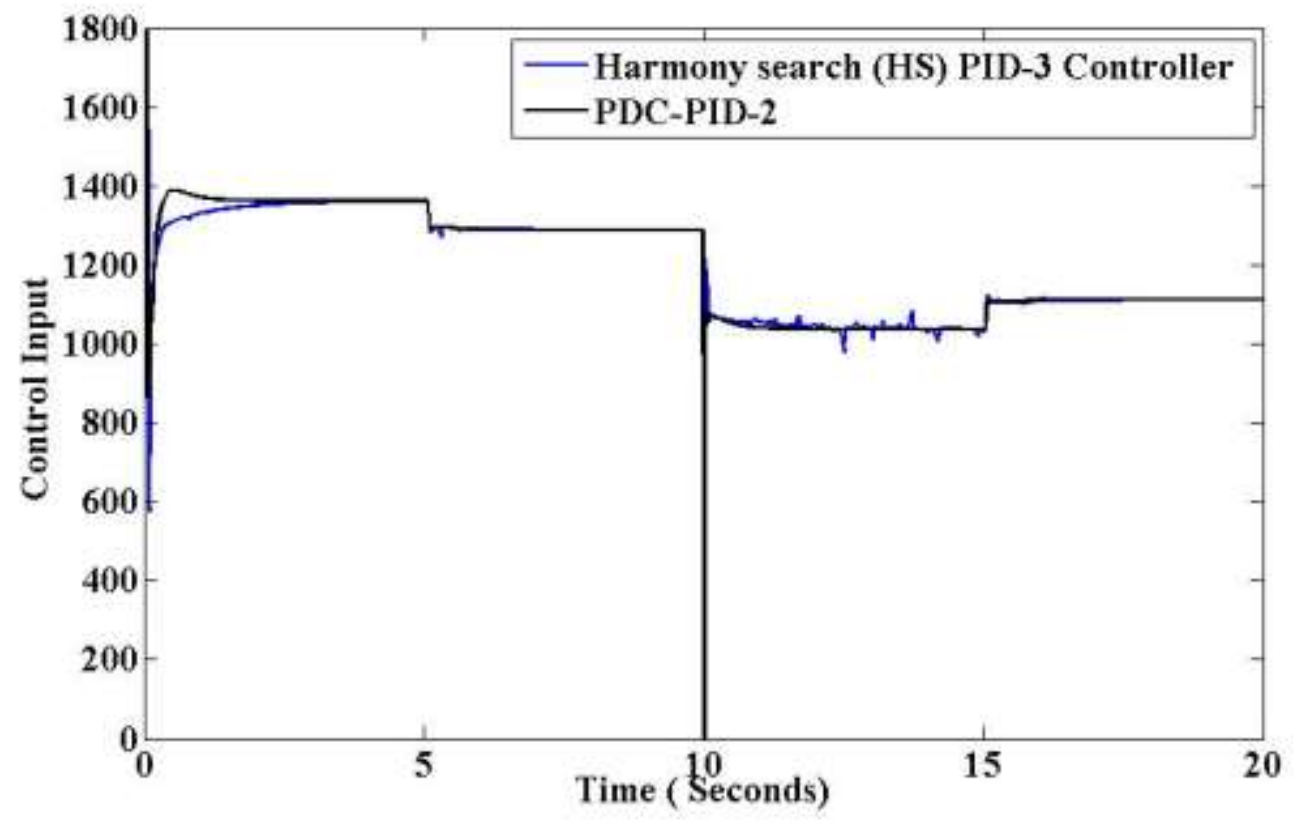

Fig. 17. The control input response at PDC-PID-2 and PID-3.

\section{CONCLUSION}

A new strategy for a Takagi-Sugeno Fuzzy Parallel Distribution Compensation- PID'S (TSFPDC-PID'S) was implemented to enhance the dynamic response of DC motor. The parameters of the operating points of DC motor considers as input to a Takagi-Sugeno Fuzzy model. The proper optimal PID controller was selected using the Takagi-Sugeno Fuzzy model for a certain operating point. The ACS optimization algorithm used to optimize the parameters values of PID'S controllers at different operating points according to the selected cost function. Several types of disturbances, uncertainty and parameters variations applied on the system to ensure the validation of proposed controller. The simulation results provided that the Parallel Distribution Compensation- PID'S can select the appropriate PID controller at different operating points so, it has a good performance through different kinds of disturbances compared to fixed PID controller. 


\section{ACKNOWLEDGMENTS}

I would like to express my special thanks of prof. Abdel Ghany Mohamed for his supporting through this work. 


\section{REFERENCES}

[1] Elgerd O. I, "Electric energy systems theory: An introduction”, McGraw-Hill; 1971.

[2] Elgerd O. I, and Fosha E., "Optimum Megawatt-Frequency Control of Multi-area Electric Energy Systems”, IEEE Transactions on Power Apparatus and Systems, Vol. PAS-89, No. 4, pp. 556-563, April 1970.

[3] Fosha E. and Elgerd O.I, "The Megawatt-Frequency Control Problem: A new Approach via Optimal Control Theory", IEEE Transactions on Power Apparatus and Systems, Vol. PAS-89, No. 4, pp. 563-576, April 1970.

[4] Wood, A.J. and Wollenberg, B.F., "Power Generation Operation and Control", John Wiley and Sons Inc., New York 1994.

[5] Tripathy S.C., Hope G.S. and Malik O.P, "Optimization of Load-Frequency Control Parameters for Power Systems with Reheat Steam Turbines and Governor Dead-band Nonlinearity", IEE Proceedings of Generation, Transmission and Distribution, Vol. 129, Pt. C, No. 1, pp. 10-16, 1982.

[6] P. Kundur, "Power System Stability and Control”, McGraw-Hill, 1994.

[7] Mostafa H. E., “Artificial Intelligence-Based Load Frequency Control of Multi-Area Power Systems”, Ph.D. Thesis, Faculty of Engineering, Ain Shams University, Cairo, Egypt, 1999.

[8] Yassin K., Abd-Raboh E. and Al-Domany M.S., "Fast Power System Restoration Via Load Shedding Practices in Egyptian Power System”, Mansoura Eng. Journal, Vol. 17, pp. 1-20, Egypt, 1992.

[9] Egyptian Electricity Holding Company, 2007/2008 Annual Report. http://www.egelec.com/annual\%20report/.htm, 2007.

[10] Mostafa H. E., "Load Frequency Control of the Egyptian Power System Using Bacterial Foraging Algorithm", Portsaid Engineering Journal, Sept. 2012.

[11] G. Magdy, G. Shabib, Adel A. Elbaset, Thongchart Kerdphol, Yaser Qudaih, Hassan Bevrani, Yasunori Mitani, " A Novel Design of Decentralized LFC to Enhance Frequency Stability of Egypt Power System Including Wind Farms", International Journal on Energy Conversion, January 2018, Volume 6, Issue 1, pp. 17-29.

[12] M. A. Abdel Ghany "Artificial Intelligent and Static Output Feedback Controllers for Power System Load Frequency Control", M.Sc. Dept. of Electrical Power and Machines Engineering Faculty of Engineering, Helwan, Helwan University, Egypt, 2014.

[13] L. Pingkang, Z. Hengjun and L. Yuyun, "Genetic Algorithm Optimization for AGC of Multi-Area Power Systems," TENCON '02, Proc. of the IEEE Region 10 Conf. on Computers, Communications, Control and Power Eng. Vol.3, pp. 1818- 1821, 2002.

[14] Rerkpreedapong, D., et al., Robust Load Frequency Control Using Genetic Algorithms and Linear Matrix Inequalities, IEEE Transactions on Power Systems, 18(2): 855 - 861, 2003.

[15] M. S Yousuf, H. N. Al-Duwaish and Z.M. Al-Hamouz, :PSO Based nonlinear Predicitive Cobtrol of Single Area Load Frequency", IFAC Conference on Control Applications of Optimization, IFAC-CAO, Finland. May 6-8, 2009.

[16] Bensenouci, A., et al., Simulated Annealing and Dynamic Programming Based Optimum Discrete-Time Output Feedback for a Three-Area Decentralized Load Frequency Control, Proc. 6th CIGRE, Cairo, Egypt, 2005. 
[17] Bensenouci, A. , et al., Optimal Discrete-Time Output Feedback Control for Multi-Area Load Frequency Control Using Evolutionary Programming, Proc. IEEE Int. Symposium on Industrial Electronics, ISIE2005, Dubrovnik, Croatia, 2005.

[18] E. S. Ali and S. M. Abdel-Elazim,"Bacteria Foraging Optimization Algorithm Based Load Frequency Controller For interconnected Power System" International Journal of Power \&Energy Systems, Volume 33, issue 3, March, Pages 633-638, 2011.

[19] Daneshfar F. and Bevrani H. "Load-Frequency Control: a GA-Based Multi-Agent Reinforcement Learning”, IET Generation, Transmission \& Distribution, Vol. 4, Iss. 1, pp 13-26, 2010.

[20] M. A. Abdel Ghany, A. M. Abdel Ghany, A. Bensenouci, M. A. Bensenouci, M. Nazih Syed Ahmad, "Fuzzy Fractional-Order PID Tuned via Relative Rate Observer for the Egyptian Load Frequency Regulation", Accepted to be published in The Twentieth International Middle-East Power Systems Conference (MEPCON) Cairo University, Cairo, Egypt, December 18-20, 2018.

[21] M.A. Abdel Ghany, A.M. Abdel Ghany, A. Bensenouci and M.A. Bensenouci "Fractional-Order Fuzzy PID for the Egyptian Load Frequency Control" Accepted to be published in The Eighteenth International Middle East Power Systems Conference MEPCON 2016, 27-29 December 2016, Helwan University, Egypt.

[22] M. A. Abdel Ghany, M. E. Bahgat,, W. M. Refaey and F. N. Hassan " Design Fuzzy Self Tuning of Optimal PID Load Frequency Controller for the Egyptian Power System Journal of Al Azhar University Engineering Sector, Vol.12, No.42, January, 2017.pp:77-89.

[23] M. A. Abdel Ghany, M. E. Bahgat, W. M. Refaey, F. N. Hassan" Design of Fuzzy PID Load Frequency Controller Tuned by Relative Rate Observer for the Egyptian Power System " 9th International Conference on Electrical Engineering ICEENG-9, Cairo, Egypt, May 27-29, 2014.

[24] M. A. Abdel Ghany, H. Abdel Magid, M. Abdullah Eissa , M. E. Bahgat , A. Bassuiny and Soliman Sharaf," Practical Implementation for Fuzzy Self Tuning of Optimal PID Controller to Servo Permanent Magnet Synchronous Motor" Journal of Al Azhar University Engineering Sector, Vol.12, No.45, October, 2017.pp:13711386

[25] K. Tanaka and H. Wang, "Fuzzy Control Systems Design and Analysis: A Linear Matrix Inequality Approach", New York: Wiley, 2001.

[26] T. Guerra, L. Vermeiren, “LMI-based Relaxed Non quadratic Stabilization Conditions for Nonlinear Systems in the Takagi-Sugeno's Form”, Automatica, Vol.40, pp. 823-829, 2004.

[27] H.A. Shayanfar, H. Shayeghi A. Jalili," Takagi-Sugeno Fuzzy Parallel Distribution Compensation Based ThreeArea LFC Design" IJTPE Journal, Volume 3,PP.55-64,2011.

[28] A. Jalili, H. Shayeghi and H.A. Shayanfar, "T-S Fuzzy Parallel Distribution Compensation Controller for Power System Stabilizer", 5th International Conference on Technical and Physical Problems of Engineering (ICTPE2009), pp. 180-184, Bilbao, Spain, 3-5 September 2009.

[29] Ho WK, Hang CC, Cao LS. Tuning of PID controllers based on gain and phase margin specifications. Automatica;31(3):497-502, 1995.

[30] Dorigo M, V. Maniezzo and A. Colorni, Ant system Optimization by a colony of cooperating agents”, IEEE Transaction on Systems Man and cybernetics - part B, 26 (1), pp. 29-41. 1996.

M. A. Abdel Ghany et al., IJAEBS (2021), (2), (1), (36-58) 
[31] Karl O. Jones, André Bouffet,. Comparison of Ant Colony Optimization And Differential Evolution. International Conference on Computer Systems and Technologies- CompSysTech’07. 2007.

[32] Hadi Nobahari, Seid H. Pourtakdoust, Optimization of Fuzzy Rule Bases using Continuous ant Colony System. Proceeding of the first International Conference on Modeling, Simulation and Applied optimization, Sharjah, U.A.E, February 1-3, 2005.

[33] Q. Zeng and G. "Tan .Optimal Design of PID Controller Using Modified Ant Colony System Algorithm", IEEE, 3rd International Conference on Natural Computation (ICNC), 2007.

[34] A.H. Besheer and A. Bensenouci," Voltage and Power Regulation for a Sample Power System using Ant Colony System Based PID controlle", Journal of Electrical Systems 8-4 , pp. 397-410, 2012

[35] F.Hassan, A.Wakeel, A.Kamel and A.Abdel-hamed. "Optimum Tuning of PID Controller for a Permanent Magnet Brushless Motor", Proceedings of the 8th ICEENG Conference, 29-31 May, 2012.

[36] M. A. Shamseldin, A. A. El-samahy, and A. M. A. Ghany, "Different Techniques of Self-Tuning FOPID Control for Brushless DC Motor,” in MEPCON, 2016.

[37] M. Omar, M. A. Ebrahim, A. M, and F. Bendary, “Tuning of PID Controller for Load Frequency Control Problem via Harmony Search Algorithm,” Indones. J. Electr. Eng. Comput. Sci., vol. 1, no. 2, pp. 255-263, 2016.

[38] M. Omar, A. M. A. Ghany, and F. Bendary, "Harmony Search based PID for Multi Area Load Frequency Control Including Boiler Dynamics and Nonlinearities,” WSEAS Trans. CIRCUITS Syst., vol. 14, pp. 407-414, 2015.

[39] M. A. K. El-shafei, M. I. El-hawwary, and H. M. Emara, "Implementation of Fractional - Order PID Controller in an Industrial Distributed Control System," in 2017 14th International Multi-Conference on Systems, Signals \& Devices (SSD) Implementation, 2017, no. 3, pp. 713-718.

[40] M. A. Shamseldin and A. A. El-samahy, "Speed Control of BLDC Motor By Using PID Control and Self-tuning Fuzzy PID controller," 2014. 


\section{BIBLIOGRAPHY OF AUTHORS}

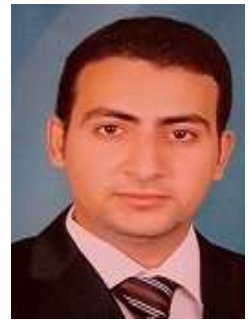

Dr. Shamseldin obtained the Bachelor of mechatronics engineering in 2010 from faculty of engineering, Helwan University, Cairo, Egypt. In 2016, he obtained an M.Sc. in system automation from faculty of engineering, Helwan University, Cairo, Egypt. In 2020, he obtained a Ph.D. in Mechatronics Engineering from faculty of engineering, Helwan University, Cairo, Egypt. Also, Mohamed was a member of mobility staff to teach in a summer course at the University of Central Lancashire, Preston, UK.

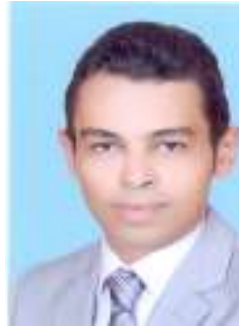

Dr. M A. Abdel Ghany was born in Cairo 22thJuly1988. He received his B. Sc from Higher Technological Institute (Tenth of Ramadan City) 2011, Diploma and M.Sc. in Automatic Control (2012 to 2014) from, Helwan University, Cairo, Egypt. From 20/6/2015 to 2018 he worked as an Assistant Lecturer at Faculty of Computer science Nahda University, Bani Sweif City. He obtained his Ph. D in Automatic Control branch in Faculty of Engineering, Helwan University, Egypt. Now, he worked as a Lecturer at department of Electrical Engineering, Faculty of Engineering October 6 University, Egypt. 